DOI: 10.52950/TE.2021.9.1.006

\title{
THE EVALUATION OF QUALITY TEACHING METHODS IN RESEARCH AT CZECH REPUBLIC.
}

\author{
JANA MARIE SAFRANKOVA, MARTIN SIKYR
}

\begin{abstract}
:
The evaluation of the quality of teaching and the evaluation of education at universities, methods of evaluating teaching and assessment are one of the key criteria for university evaluation. At present, a project of the ESF project of the University of West Bohemia in Pilsen was realized and one of its activities is focused on "Improving Educational Activities and Modern Educational Trends" and on the subsequent implementation and reflection of student education with new teaching methods. The questionary survey was conducted in 2019 with 616 respondents from the University of West Bohemia in Pilsen, who is the only one public higher education institution in the Pilsen Region. The results analyze in detail the views of the students - taking into account the extension of pedagogical competencies within the framework of the career order. The aim of the project is a comprehensive system of interconnection of the education of academic staff in the area of increasing pedagogical competencies with introduction of new teaching methods into practice and taking into account the extension of pedagogical competencies within the framework of the career order. The results of a survey focused on evaluating the quality of teaching methods confirmed a number of mostly known means of activating teaching, interactive teaching, communication, discussion, the role of the personality of the lecturer and the instructor. These activation approaches need to be continued.
\end{abstract}

\section{Keywords:}

quality of teaching, methods of teaching, educational activity, university, student, research

JEL Classification: $120,121,123$

\section{Authors:}

JANA MARIE SAFRANKOVA, Ambis University, a.s. and West Bohemia University in Pilsen, project centre, Czech Republic, Email: jsafrankova@gmail.cz

MARTIN SIKYR, Ambis University, a.s. and West Bohemia University in Pilsen, project centre, Czech Republic, Email: martinsikyr@seznam.cz

\section{Citation:}

JANA MARIE SAFRANKOVA, MARTIN SIKYR (2021). The evaluation of quality teaching methods in research at Czech Republic.. International Journal of Teaching and Education, Vol. IX(1), pp. 75-85., 10.52950/TE.2021.9.1.006 


\section{Introduction}

The content of this article is based on research at The University of West Bohemia in Pilsen in two ESF projects of this university (2017 - 2022). The article is based on authors longitudinal research by many projects concerning to quality of teaching and on last results research on methods of teaching at the University of West Bohemia in Plzeň in Czech Republic. The approaches are based on three steps of this research, the first was realised in year 2017 as analyses of rules of the system of quality assurance of educational, creative and related activities and internal evaluation of education of the University of West Bohemia. The second step was realised in year 2018 as pilot research and main results was published in this journal in article the quality assessment methods of teaching in Czech Republic (Safrankova et all, 2019). In 2019, the ESF project of the University of West Bohemia in Pilsen (CZ.02.2.69 / 0.0 / 0.0 / 16_015 / 0002287) and its activities 2 focused on "Improving educational activities and modern teaching trends" and the subsequent implementation and reflection of students' education with new teaching methods.

The analysis of teaching methods aims not only to improve the educational process, but above all to direct educational methods to the activity of students so that educational methods meet the needs of current students. To analyse the quality of teaching and the educational process, the survey used the method of questionnaire research in 2019 in connection with in-depth interviews with students, which took place in 2018. The survey was focused on 616 students of all faculties of the UWB. The results of the questionnaire survey are used to expand (accurate classification, delimitation, definition) of activation methods of teaching at all nine faculties of the University of West Bohemia.

Analyses of quality of teaching methods at universities, in the area of Europeans documents are pointed in earlier declarations aimed at harmonizing the construction of the European Higher Education System. The Sorbonne Declaration of 1998 states that "Europe... must be a Europe of knowledge... It must be universities that will largely create this dimension and will play a major role in its development... and work will undergo major changes to diversify vocational education where lifelong learning becomes a clear obligation. We owe our students and our society a higher education system in which they are given the best opportunities to seek and find their areas of excellence." (European Higher Education Area, 1999).

All other successive European Councils have consistently stated that European universities must contribute to the creation of a Europe of knowledge. "The ways of living and working are changing rapidly. This means not only that individuals have to adapt to change, but also that established ways of working must be changed... to accompany a successful transition to a knowledge-based economy and society. That is why European education systems are at the core of the upcoming changes" (European Higher Education Area, 1999).

These long-term approaches are also reflected in the Amendment to the Higher Education Act, approved in 2016. This obliges universities to ensure the quality of educational, creative and related activities and the internal quality assessment of these activities in Section 77b. The text of the Act states that: "The university is obliged to implement and maintain a system of quality assurance of educational activities in cooperation and mutual relations of the university with other universities, public research institutions and other legal entities engaged in research, 
experimental development or innovations, employers of graduates, entrepreneurs in the industrial and commercial spheres, business associations and other persons or bodies performing, supporting or using the educational or creative activities of universities or its results." (Amendment to the Higher Education Act, 2016). European Strategy 2030 towards universities declare necessity to increase analyses on quality of teaching and compare their approaches to new teaching methods.

In theoretical approaches we find many Czech authors who are concentrated to educational methods. (Vasutova, 2002, Safrankova, Sikyr, 2018, 2019 Tureckiova, Veteska, 2008; Veteska, 2013). Continuous improvement of teaching must be permanently implemented in the pedagogical process, which requires increased demands on students and teachers, systematic awareness, explanation of the benefits of change for both parties, training of teachers and methodological assistance, including the use of feedback mechanisms such as teaching assessment, teacher satisfaction surveys and students. (Lorencová, 2017)

\section{Goal and methods}

The goal of article is to analyse approaches to analyses of quality teaching methods and opinions of surveyed students.

In 2019 was established a questionnaire survey focused on the evaluation of quality teaching methods. In addition to conducting structured interviews with students, the team of university staff in the ESF project is also preparing an assessment of the quality of teaching by the teachers themselves. The aim of the University of West Bohemia is to create a comprehensive system of interconnection of education of academic staff in the field of increasing pedagogical competencies with the introduction of new teaching methods into practice.

The questionnaire survey took place in the summer semester of the academic year $2018 / 2019$ in May, June and September 2019. Its aim was to obtain as many suggestions as possible to improve the quality of teaching methods. This targeted intention of the questionnaire survey on the one hand brought very good and detailed results on the quality of teaching methods, on the other hand it is necessary to emphasize that the results contain only a small number of negative attitudes and opinions and are influenced by students' efforts to contribute to improving teaching methods.

With regard to the goal of gaining the best possible view of teaching methods, more active, motivated students were approached and obtained, who were present at the teaching. Again, the interviewers were students who, according to instructions, addressed students in teaching according to a sample of representativeness. The overall results show that the addressed students are interested in the study program or field of study, that they study mainly for good future employment in the labour market and that they are generally satisfied with the study at individual faculties.

The research questions is: Which teaching methods to development of knowledge and abilities university students prefer and why? 
The questionnaire identifies respondents (faculty, year, field of study, study average, gender), questions about students' opinions on study, such as their interest in study, field of study, favourite and unpopular subjects, overall satisfaction with the study at the University of West Bohemia and possible experience from studying abroad.

There are 32 key questions, focusing on different perspectives on the evaluation of individual teaching methods. The respondents answer the questions as to how they would ideally study the field of study at university (ratio of lectures, exercises, other activities) and which activities motivate them to learn, anchor knowledge and develop skills, including the development of analytical and critical thinking. In the second key part of the in-depth interview, respondents describe in detail the reality of using and evaluating teaching methods in terms of creating and fixing knowledge and skills development (breakdown into lectures, exercises and other teaching methods), giving examples of good practice but on the other hand approaches of teachers.

The questions also deal with the way of lecturing and the approach of teachers to students in seminars and tutoring seminars. Since most of the courses at the University of West Bohemia are processed in the STAG system in the methodology of learning outcomes, students are also asked about the relation of teaching to these learning outcomes. In the final questions there are also questions about the environment in the classrooms and the schedule of lessons depending on the activity and motivation of the student to study.

In survey were students of undergraduate and postgraduate study programs at all nine faculties of the University of West Bohemia. In this year at these programs were studying 9000 students. Sample was $7 \%$ of all students. For date was used questionnaire with 39 questions.

\section{Results and discussion}

The structure of the respondents reflects the opinions of students from nine faculties: from the Faculty of Applied Sciences 20 students, from the Faculty of Design and Art L. Sutnar - 54 students, from the Faculty of Economics - 65 students, from the Faculty of Electrical Engineering 82 students, from the Faculty of Philosophy - 35 students, from the Faculty pedagogical - 124 students, from the Faculty of Law - 65 students, from the Faculty of Mechanical Engineering 73 students, and, from the Faculty of Medical Studies 98 students.

According to gender, half of the men (307 in total) and half of the women 's sample (309 in total) from the total number of 616 respondents are represented in the sample. According to the type of faculty and studied study programs, quite logically at FAV, FEL and FST men significantly outweigh the number of women, which fully corresponds to reality, and at FDU and FZS the number of women significantly outweighs the number of men. In the economic study programs - FEK, at FF and FPE and FPR, one third of the respondents are men and two thirds of women, with certain, statistically insignificant differences in terms of the sample.

Most of the interviewed 616 students from in Pilsen agreed on the importance of activation methods in lectures, most emphasize the great importance of exercises for the development of knowledge and skills and various examples from practice. For critical and analytical thinking, it is confirmed that tasks, projects, discussions and practical examples are important, less so in team work. Contrary to the results of in-depth interviews, the only things that were not confirmed 
by the questionnaire survey are homework and homework, which students emphasized as very important in the interviews. $45 \%$ of respondents would prefer home preparation for teaching and, on the contrary, $55 \%$ do not agree. $23 \%$ are in favour of introducing compulsory attendance at lectures. i.e. one quarter of respondents disagree, i.e. $77 \%$ of respondents agree with the current state of optional participation in lectures.

\section{Evaluation of teaching methods in terms of knowledge, skills, thinking of the student}

Teaching methods in terms of expanding students' knowledge.

The majority of students - $95 \%$ are satisfied with the exercises, then the practice $74 \%$ and $71 \%$ of the lecture. Other teaching methods are only for some study programs, ie. they are not widely used - studios were mentioned by a total of $25 \%$ of respondents, of which $16 \%$ evaluate them very positively, which is the majority of those who use them. The laboratories were mentioned by a total of $40 \%$ of respondents who have them in their study programs, of which $33 \%$ evaluate them very positively, which is the majority of those who use them. Overall, $33 \%$ of respondents who use them in their study programs use listening in them, of which $22 \%$ evaluate them positively, which is the majority of those who use them.

Teaching methods in terms of developing students' skills. For most students - $94 \%$ are satisfied with the exercises, then the internships $78 \%$ and $46 \%$ of the lecture. Other teaching methods are only for some study programs, i.e. $25 \%$ of respondents stated that they are not widely used in studios, of which $16 \%$ evaluate them very positively, which is the majority of those who use them. The laboratories were mentioned by a total of $36 \%$ of respondents who have them in their study programs, of which $33 \%$ evaluate them very positively, which is the majority of those who use them. In total, $30 \%$ of respondents who use them in their study programs use listening in them, of which $17 \%$ evaluate them positively, which is more than half of those who use them.

Table 1 Which interpretation techniques suit in lectures?

\begin{tabular}{lrccc}
\hline Lecturer & $\begin{array}{l}\text { Definitely } \\
\text { yes }\end{array}$ & Rather yes & Rather no & $\begin{array}{c}\text { Definitely } \\
\text { yes }\end{array}$ \\
\hline Only interprets & $10 \%$ & $35 \%$ & $41 \%$ & $13 \%$ \\
\hline Writing on the blackboard & $23 \%$ & $51 \%$ & $21 \%$ & $5 \%$ \\
\hline Discussed with students & $45 \%$ & $38 \%$ & $15 \%$ & $1 \%$ \\
\hline Use of visual aids & $59 \%$ & $34 \%$ & $6 \%$ & $1 \%$ \\
\hline $\begin{array}{l}\text { Providing of examples of } \\
\text { theory applications }\end{array}$ & $72 \%$ & $24 \%$ & $4 \%$ & $1 \%$ \\
\hline $\begin{array}{l}\text { Providing of examples from } \\
\text { practice }\end{array}$ & $84 \%$ & $14 \%$ & $2 \%$ & $0 \%$ \\
\hline \begin{tabular}{l} 
Use of videos \\
\hline
\end{tabular} & $35 \%$ & $40 \%$ & $19 \%$ & $6 \%$ \\
\hline
\end{tabular}

Source: Own research

In terms of teaching methods, it contributes to the development of critical thinking:

- $94 \%$ of respondents meet practical examples

- Overall, $89 \%$ of respondents are satisfied with the study of the field

- The discussion suits $89 \%$ of respondents 
- $81 \%$ of respondents agree with the teacher's opinion

- A separate task suits $80 \%$ of respondents

- Verification of the theory from lectures at seminars suits $79 \%$ of respondents

- Seminar work suits $76 \%$ of respondents

- Work on the project suits $76 \%$ of respondents

- Creating team presentations suits $53 \%$ of respondents.

In terms of teaching methods, it contributes to the development of analytical thinking:

- Examples from practice suit $93 \%$ of respondent.

- Overall, $92 \%$ of respondents are satisfied with the study of the field

- The discussion suits $88 \%$ of respondents

- A separate task suits $83 \%$ of respondents

- Seminar work suits $80 \%$ of respondents

- Work on the project suits $79 \%$ of respondents

- The opinion of the teacher is satisfied by $79 \%$ of respondents

- Verification of the theory from lectures at seminars suits $78 \%$ of respondents.

- Team creation of presentations suits $58 \%$ of respondents

In terms of teaching methods, it contributes to the development of complex thinking:

- Case studies suit $98 \%$ of respondents

- Examples from practice suit $96 \%$ of respondents

- Overall, the study of the field suits $95 \%$ of respondents

- The opinion of the teacher is satisfied by $79 \%$ of respondents

- Work on the project suits $75 \%$ of respondents

- Seminar work suits $68 \%$ of respondents

- Team creation of presentations suits $54 \%$ of respondents

Teaching that will activate students to learn should include examples from practice, from life $97 \%$ of respondents; combination of interpretation with practical example - $96 \%$ of respondents; interesting interpretation - $96 \%$ of respondents; dialogue of the lecturer with students $-86 \%$ of respondents; interactive approach - $86 \%$ of respondents; connection of interpretation with excursion $-83 \%$ of respondents.

Teaching motivating to learn according to the respondents is one that includes mainly internships and excursions - $89 \%$ of respondents, activation in teaching - $81 \%$ of respondents, teamwork $-68 \%$ of respondents, seminar work - $62 \%$ of respondents, repetitive tests $-55 \%$ of respondents, obligation to present $-39 \%$ of respondents, homework $-37 \%$ of respondents.

Lectures and lecturers

Lecture as one of the main teaching methods at the university:

- Lectures are considered important by $75 \%$ of respondents. It is a positive finding about the significance of lectures for students.

- Of the students surveyed, $58 \%$ attend lectures and $37 \%$ say that sometimes, given that the students who were in the class answered, it can be assumed that the overall number of students is lower overall. Those who do not attend lectures or classes were not. 
- In terms of combining the form of lecture and lecture exercises in smaller groups, students answered that teachers use this activation method, sometimes $62 \%$ and often $28 \%$ and only a small number of students (3\% do not like this connection).

- According to students, more than half of the teachers follow the structure of the lecture $-58 \%$ agree, on the contrary, it is worth thinking that $41 \%$ stated that they do not follow the structure.

The activating lecture should contain - additional questions - $81 \%$ of respondents; materials online and during the lecture discussion with students a demonstration - $76 \%$ of respondents; smaller tasks during the lecture to think - $73 \%$ of respondents; requiring activity from the lecturer - $71 \%$ of respondents; so-called collecting points for smaller tasks or activities - $55 \%$ of respondents; smaller tasks before the lecture to think - $50 \%$ of respondents; only exceptionally a test at the beginning of the lecture, which is passed by only $16 \%$ of respondents.

Lecture techniques:

- In lectures, it is most convenient for students when the teacher gives examples from practice - $98 \%$, further gives examples of the application of theory $83 \%$ and uses visual aids - 95\%. Students also consider the discussion during the lecture to be an important activation, and $83 \%$ of the respondents stated yes and rather yes, and a total of $74 \%$ are also comfortable writing on the board.

- The least suitable for students is interpretation without examples and visual aids. Respondents state that if the teacher only explains, only $10 \%$ of respondents definitely said yes. $54 \%$ of respondents do not like it.

- The effectiveness of the lecture according to students increases the repetition of important - $96 \%$ of respondents and equally important is the volume of $98 \%$ and visual aids $-91 \%$, examples of applications are important for $95 \%$ and practical examples 97 $\%$ and answers of teachers to questions $96 \%$.

- It is confirmed that all these approaches of the teacher are very important for the effectiveness of the lecture.

According to the respondents, the most important thing for most lecturers in terms of the quality of teaching is that the lecturers:

- proves that he has very good professional knowledge, $98 \%$ of respondents are satisfied;

- responds to questions during the lecture, $95 \%$ of respondents are satisfied

- interprets the substance clearly, $93 \%$ of respondents are satisfied;

- the lecturer has a logically arranged teaching, it satisfies $86 \%$ of respondents;

- have lectures arranged in such a way that they allow them to take the necessary notes, it is suitable for $80 \%$ of respondents

- support an active approach to the subject, it suits $77 \%$ of respondents;

- presents practical applications, $76 \%$ of respondents are satisfied;

- have clear graphic information (presentations), $74 \%$ of respondents are satisfied;

- presents valuable and easily accessible literature, $72 \%$ of respondents are satisfied;

- combine theory with practice, it suits $72 \%$ of respondents;

- explain the relationships between the various parts of the study, it suits $61 \%$ of respondents. 
It is very important for lectures to be comprehensible, logically arranged, to have built-in examples of practical applications and, if possible, to connect theory with practice, and for teachers to respond to questions. The use of visual aids is also very important at most faculties. Appropriate way of organizing and conducting exercises.

Practitioners in terms of conducting exercises, communication with students are rated by respondents very highly. With the combined variant definitely yes and rather yes, all evaluations are between $98 \%$ of the agreement with the given statement and at least $70 \%$ of the positive evaluation.

Among the most important evaluations of trainees is the fact that they respond to questions during the exercise - 98\%; interpret the substance intelligibly $97 \%$; have expertise - $97 \%$; are willing to provide a consultation - 95\%; pay attention to students during exercises - $94 \%$; they have a logically arranged teaching - $91 \%$; exercises are thanks to the trainer, benefit - $90 \%$; that he can teach - $88 \%$; that the instructor presents valuable and easily accessible literature - $86 \%$; that they oppose an active approach to the subject - $86 \%$ and that they combine theory with practice $-86 \%$.

Other positive factors influencing the conduct of exercises - continuity of exercises to lectures $93 \%$; individual practice - $76 \%$; group work - $65 \%$; home preparation and its practice - $50 \%$; work on a longer-term task (project) - 47\%.

Used study materials students to gain knowledge

Students mostly use their own written notes from lectures (83\%) to gain knowledge; official visual presentation (81\%); printed script $(74 \%)$; electronic study aids $(72 \%)$; written notes from lectures from colleagues (71\%); professional publications (54\%); own unofficial records / photographs of lectures (50\%) or colleagues (45\%); E-learning (40\%) and only one-fifth reported video recordings of lectures (own)

To prepare for the exam or credit, the respondents mostly use their own notes from lectures, their own or someone else's elaborated questions, notes from lectures from colleagues, PowerPoint presentations, as well as printed scripts, electronic study aids. Unofficial recordings of lectures, professional publications, e-learning and at least one-fifth of unofficial video recordings of lectures are used less.

Suitable type of course completion. The interviewed students are most satisfied with tests with variants (92\% yes), then seminar work (66\% yes), oral examination (64\% yes), tests with open questions (54\% yes), project (52\% yes), combination of test and oral examination (42\% yes). Respondents state that examiners are objective in testing and evaluation, definitely yes said $17 \%$ and rather yes $74 \%$ of respondents. Only $9 \%$ of respondents believe that they are not.

Summary of the results of in-depth interviews to compare with the results of the questionnaire survey:

\section{Ideas for ideal teaching.}

All students are satisfied with the ratio of lectures and exercises or seminars, as an ideal ratio they stated the ratio of lectures and exercises $1: 1$. In the case of small study groups, they stated that "there is no need to differentiate, they can intersect, there should be theories and practical 
examples." , activity should be required everywhere, a lot of contact, questions, sometimes homework or elaboration and then discussion, more exercises and less lectures, the lecture and exercises should be in the near future, the week is a long time. More group projects, group work, ongoing tests."

\section{Quality teaching - lectures, exercises}

All the respondents - students more or less agree that quality teaching is one that "will entertain me and will somehow motivate me to look for it more. When a teacher can engage, I like it. The person who leads the teaching should respond and answer the students' questions, the teacher's helpfulness to the students in cases where he does not understand something, respect for the students, order and organization in the teaching. The teacher should have a syllabus. They don't have it here, and I don't like it. There should also be discussion and activity. In my opinion, it starts a lot with a teacher who lectures, because if the teacher enjoys it, it will certainly be reflected in his speech, and if he can interest me, I can get excited about things that would not interest me. It depends a lot on the teacher and my interest. Teaching that has some added value, even outside of quality lectures, ie the teacher should present it so that the student can better imagine it on a specific example and in practice. For example, through debates, for the student to gain knowledge by showing interest in it and by motivating him to do so. "

The respondents - students also emphasized in the lectures that the teacher should continuously ask questions and thus activate the students in the lecture. At the same time, there is a repeated demand for ongoing homework. "There should be room for a separate trial. And so, try it on your own to engrave it. So is the physical memory - to put it into practice that you've ever done it before. Or go to the board to know what mistakes you are making or someone else. It's better than when the teacher writes alone. Methods where the student has to defend his / her opinions so that the teaching directs students to develop an activity (a project he / she has to defend, debates), where they work on something specific and defend the result of their work or try to understand more perspectives. Obligation to present and lecture the material themselves, work in teams. We get materials and we should have homework and work from home. We should be obliged to come, hand in something and we must be internally motivated. If I have to speak specifically, I like it when we have to actively invent something ourselves. I don't like it when it comes to the teacher's explanation. I like it when we have to do something at home, send it to him by e-mail, for example, and he evaluates it and writes it to us. Everyone learns about the exam and this forces us to learn in advance. One has to create and invent something in a given topic. At the same time, he has to construct it. Think about the problem yourself. "

\section{A teaching method that develops critical thinking}

When asked which teaching methods develop critical thinking, the respondents - students, for example, stated, "Independent task on a project - semester work. It occurs to me that this is an ideal seminar when we can debate with a teacher. Basically, the cantor builds it in the student, because if the cantor doesn't tell him that it doesn't always have to be that way, then of course, as students, it doesn't bother us right away if we don't completely orient ourselves in it. More people in the classroom - more opinions, perspectives, practice, task development and teacher feedback. Discussions, conducting interviews, opposing the topic, creating team presentations. In my opinion, this should be a teaching method where they give us two different views and we should deduce our own. Using multiple sources from which we form our own opinion. It should not just look at the information one remembers, but whether one understands it. That's the basis 
for me. The exam should have a part with open tasks, it should be about testing the ability to respond to the problem, solve it. Not just by listing a lot of information. But he has to think about it and solve the problem. A learned path, but not by heart."

Results in survey show that students who are interested in studying and studying the field are generally satisfied with the teaching methods at the UWB. At the same time, all respondents agreed that they preferred activating teaching methods, both guided discussions and group work, guided discussion within the group and its presentation. In terms of lectures, they prefer lectures with activating elements, in which the teacher continuously asks questions and students answer them. An important stimulus for reflection can be considered the repeatedly repeated requirement for home preparation during the semester and, based on it, work in exercises or seminars. Although, as mentioned at the beginning of this section, students often responded motivated to study, it is positive that the negative elements in teaching were only rarely reflected. Overall, the interviews show a relatively high level of satisfaction with current methods used in teaching.

\section{Conclusion}

The results of a survey focused on evaluating the quality of teaching methods confirmed a number of mostly known means of activating teaching, ie. interactive teaching, communication, discussion, the role of the personality of the lecturer and the instructor. These activation approaches need to be continued.

Relatively different opinions of students compared to a number of previous surveys in the Czech Republic and in the world, brought several important confirmations of changes in trends in higher education. The results of the survey show a very strong moment of orientation to practical examples, application of theory to practice and practical use of acquired knowledge and skills. This offers a continuation of the discussion on the role of higher education in relation to the direct practical application of knowledge and skills (which rather belong to professionally oriented higher education programs). Today's students, although they proclaim the expansion and deepening of knowledge, still emphasize their rapid practical application. Two "new factors" emerged in the survey in terms of teaching organization, namely a possible return to compulsory lectures and homework assignments (although this is contrary to the principles of higher education, but at the same time the current situation suits half of the respondents).

The results of the survey in two phases - structured interviews and questionnaire survey result in recommendations for further, systematic development of activation methods of teaching, but also for the development of soft skills of university teachers (interpretation, presentation, structure of interpretation, nonverbal communication, discussion, use of projects in teaching, etc.)

For further research, it is recommended to focus on the reasons for the small number of students leaving for ERASMUS, to continuously monitor students' views on the obligation to attend lectures, or interest in preparation for teaching during the semester (foreign universities have long required independent preparation for teaching). 


\section{References}

EUROPEAN HIGHER EDUCATION AREA. (1999) Joint Statement by the Ministers of Education of the European States at the meeting in Bologna.

KEY DATA ON TEACHERS AND SCHOOL LEADERS IN EUROPE. (2013). European Commission. Joint Declaration on the harmonization of the construction of the European Higher Education System. (1998) Paris, Sorbonne

LORENZOVA J. (2017). Childhood through the lens of social pedagogy. International Journal of Social Sciences, Vol. VI (1), pp. 53-70. DOI: 10.20472/SS2017.6.1.005.

MEMORANDUM ON LIFELONG LEARNING (2000) EU. http://memorandum.nvf.cz

ŠAFRÁNKOVÁ, J. M., \& ŠIKÝŘ, M. (2018). Responsibilities and competencies in personnel management at Czech schools. Oeconomia Copernicana, 9(3), 529-543. DOI:10.24136/oc.2018.027

ŠAFRÁNKOVÁ, J. M., ŠIKÝŘ, M. \& J. COUFALOVÁ (2019). The quality assessment methods of teaching in Czech Republic. International Journal of Teaching and Education, Vol. VII (2), pp. 12-21., DOI: 10.20472/TE.2019.7.2.002

TURECKIOVÁ, M. VETEŠKA, J. (2008) Competences in education (Kompetence ve vzdělávání). Praha, Grada. ISBN 978-80-247-1770-8

VAŠUTOVÁ, J. (2002). Strategie výuky ve vysokoškolském vzdělávání. (Teaching strategies in higher education). Praha: UK, Pedagogická fakulta.

ACT NO. 111/1998 COLL., On Higher Education Institutions and on Amendments to Other Acts (Higher Education Act). Zákon č. 111/1998 Sb., o vysokých školách a o změně a doplnění dalších zákonů (zákon o vysokých školách). (online) Dostupné z: http://www.msmt.cz/vzdelavani/vysokeskolstvi/legislativa

\section{Acknowledgment}

This paper was supported by University of West Bohemia, Pilsen, Czech Republic (CZ.02.2.69 / 0.0 / 0.0 / 16_015 / 0002287) "Improving Educational Activities and Modern Educational Trends" 